\title{
The Factors Affecting Job Satisfaction of Emergency Medical Services Professionals in Ankara
}

\author{
İshak Șan (1) \\ Department of Emergency Medicine, University of Health Sciences, Ankara Numune Training and Research Hospital, Ankara, Turkey
}

ORCID ID of the author: i.Ș. 0000-0002-9658-9010.

Cite this article as: Șan I. The Factors Affecting Job Satisfaction of Emergency Medical Services Professionals in Ankara. Cyprus J Med Sci 2019; 4(3): 177-82.

\section{BACKGROUND/AIMS}

The aim of the present study was to determine the job satisfaction level of emergency medical services (EMS) professionals and factors affecting job satisfaction.

\section{MATERIALS and METHODS}

The study included 78I EMS professionals in Ankara, Turkey and was conducted from September 2018 to November 2018. A semistructured questionnaire including socio-demographic data and Minnesota Job Satisfaction Scale was used in the study.

\section{RESULTS}

The mean score of internal satisfaction of the participants was $3.4 \pm 0.6$, whereas the mean score of external satisfaction was $2.9 \pm 0.7$, and the overall mean score was $3.2 \pm 0.6$. There was a significant difference between gender and external satisfaction scale score ( $p<0.05$ ). External and general satisfaction scores of female employees were significantly lower than those of male employees.

\section{CONCLUSION}

External satisfaction level of EMS professionals is low. Problems related to access to management, participation in management, career opportunities, wages, security, being appreciated, and prevention of violence negatively affect job satisfaction.

Keywords: Emergency medical services, health professionals, job satisfaction

\section{INTRODUCTION}

Emergency medical services (EMS) are a labor-intensive work field. The contribution of the professionals working in this field to the quality, efficiency, accessibility, health expenditures, and satisfaction of the service is very important (I, 2). Therefore, maximizing employee performance directly affects the efficiency of the service. Performance is highly influenced by job satisfaction. Employees who are satisfied with their jobs have been shown to be more productive and more committed to their own organizations (I-4).

Job satisfaction can be defined as the emotional response of the individual to the fulfillment of his/her job requirements (physical, psychological, and social) (4-7). Studies have shown that job satisfaction of health professionals is affected by many factors, such as gender, age, education level, work experience, working conditions, salary, working hours, and promotion opportunities $(8,9)$. In addition to these factors, the characteristics of the work environment also significantly affect job satisfaction (I0).

In general, psychological problems, such as stress, fatigue, burnout, and depression, in health services affect job satisfaction and therefore health care systems. The most stressful area in health services is EMS (9-II). Pre-hospital professionals often face many stressors, such as working for long hours, frequent exposure to traumatic events, time pressure, negative weather conditions, serving in insecure environments, and violence. These stressors can lead to reduced job satisfaction over time, burnout, physical and psychological problems, serious labor loss, and abandonment of the profession (II, I2). 
In the studies conducted, it was stated that the burnout levels of the ambulance professionals were high, and that this would affect the patient care and the quality of the service provided $(10,11,13)$. Reduction in job satisfaction may be a trigger for many mental problems, such as burnout, anxiety, depression, and suicide (|4).

Considering all these factors, it is very important to know the job satisfaction levels of the EMS professionals with respect to increasing the quality and productivity in health services. Although many studies have been conducted on health care professionals, there are few studies on EMS professionals. The aim of the present study was to determine the job satisfaction levels of EMS professionals and the factors affecting job satisfaction.

\section{MATERIALS and METHODS}

The study was approved by the ethics committee of Ankara Yıldırım Beyazıt University (date 18/09/2018, no. 4I). Written informed consent was obtained from the individuals who participated in the study.

In this descriptive research, the questionnaire technique was used as the quantitative method, and the focus group interview technique was used as the qualitative method.

\section{Participants}

The study consisted of health professionals working in ambulances or call center of the EMS in Ankara, Turkey. In the present study, the simple random sampling method was used. The questionnaires were distributed to all health professionals by the researcher, and they were collected after they were answered. The professionals who accepted to fill out the questionnaires voluntarily formed the sample of the study. Of these, 1757 were health professionals (II3 doctors; 99 nurses, midwives, or public health technicians; $|13|$ emergency medical technicians; and 414 paramedics), and 604 were other staff (secretaries, cleaning staff, and drivers, and so on).

The study was conducted on 781 participants from September 2018 to November 2018. The criterion in the sample selection was "volunteering to fill out the surveys." Overall, 755 refused to participate in the study, whereas 221 were unavailable. All the questionnaires and scales used in the study were given to the employees individually, and the questionnaires were delivered to the researchers after completion.

\section{Data Collection Forms}

The socio-demographic data form was developed by the researcher as a result of the literature review, whereas the Minnesota Job Satisfaction Scale (MJSS) and semi-structured questionnaire were used in the study.

The socio-demographic data form consists of nine questions on gender, age, marital and educational status, having children, income and occupational data, professional experience, and seniority years in pre-hospital field.

Minnesota Job Satisfaction Scale is a 20 -item scale developed by Weiss, David, England, and Lofquist to measure job satisfaction (I5). It was translated into Turkish by Baycan; validity and reliability studies were performed (Cronbach's alpha=0.77) (16). It is a 5-point Likert-type scale. There is no inverse question in the scale. The MJSS consists of 20 items that measure the internal, external, and general levels of satisfaction. While the general satisfaction score is the arithmetic mean of all items, the internal satisfaction score is the arithmetic mean of the $1^{\text {st }}, 2^{\text {nd }}, 3$ rd $, 4^{\text {th }}, 7^{\text {th }}$, $8^{\text {th }}, 9^{\text {th }}, 10^{\text {th }}, 11^{\text {th }}, 15^{\text {th }}, 16^{\text {th }}$, and $20^{\text {th }}$ items, and the external satisfaction score is the arithmetic mean of the $5^{\text {th }}, 6^{\text {th }}, 12^{\text {th }}, 13^{\text {th }}, 14^{\text {th }}, 17^{\text {th }}$, $18^{\text {th }}$, and $19^{\text {th }}$ items. The neutral satisfaction score of the scale is 3. If the score is $<3$, it means that the job satisfaction is low. The Cronbach's alpha values for the present study were found to be 0.86 for internal satisfaction, 0.81 for external satisfaction, and 0.89 for general satisfaction.

In the evaluation of the factors affecting job satisfaction, the phenomenological (case study) method of the qualitative research was used, and the data were collected in a written form using the semi-structured questionnaire formed by the researcher. These are the following questions in the semi-structured questionnaire: "What are the positive factors that affect your job satisfaction?" "What are the negative factors that affect your job satisfaction?," and "What should be done in your workplace so that your job satisfaction will be higher than it is now?." Descriptive analysis and content analysis techniques were used in the analysis of the data, and in accordance with the original, the expressions used by the participants were included.

\section{Statistical Analysis}

Statistical analysis was performed using IBM Statistical Package for the Social Sciences Statistics, version 2I.0 (SPSS IBM Corp., Armonk, NY, USA). A p value $<0.05$ was accepted as statistically significant.

Shapiro-Wilk test was used to determine the normal distribution of the variables, and median ( $\mathrm{min}, \mathrm{max}$ ) was used for descriptive statistics. Categorical variables were expressed as number (n) and percentage (\%).

Mann-Whitney U test was used to compare the scale scores of the two independent groups, and Kruskal-Wallis test was used in more than two groups. When there was a significant difference in the Kruskal-Wallis test, the paired comparison results (Dunn's multiple comparison test) were given.

\section{RESULTS}

In our study group, $63 \%$ of the participants were females. The mean age of the participants was $31 \pm 6.3$ years, and $62 \%$ were between aged 26 and 35 years. Of the 781 participants, $71 \%$ had a bachelor's degree, 75\% were married, and 92\% had a monthly income of $>3000$ Turkish Liras. While the mean experience of the participants in the EMS field was $7.5 \pm 4.5$ years, it was $10 \pm 5.8$ years for all health services (Table I).

The internal, external, and general satisfaction levels were $3.4 \pm 0.6,2.9 \pm 0.7$, and $3.2 \pm 0.6$, respectively (Table 2 ).

When the external and general satisfaction scales are considered, there was a statistically significant difference with respect to gender variable only. Both the external and general satisfaction scale scores were significantly higher in males ( $Z=2.189$, $p=0.029$ and $Z=2.073, p=0.038$, respectively) (Table 3). 


\begin{tabular}{|c|c|c|}
\hline & $\mathrm{n}$ & f \\
\hline \multicolumn{3}{|l|}{ Age } \\
\hline 18-25 years & 175 & $23 \%$ \\
\hline $26-35$ years & 484 & $62 \%$ \\
\hline $36-45$ years & 89 & $11 \%$ \\
\hline $46-55$ years & 33 & $4 \%$ \\
\hline \multicolumn{3}{|l|}{ Gender } \\
\hline Female & 495 & $63 \%$ \\
\hline Male & 286 & $37 \%$ \\
\hline \multicolumn{3}{|l|}{ Educational status } \\
\hline High school graduate & 228 & $29 \%$ \\
\hline Bachelor's degree & 553 & $71 \%$ \\
\hline \multicolumn{3}{|l|}{ Marital status } \\
\hline Married & 586 & $75 \%$ \\
\hline Single & 152 & $20 \%$ \\
\hline Others & 43 & $5 \%$ \\
\hline \multicolumn{3}{|l|}{ Having children } \\
\hline Yes & 520 & $67 \%$ \\
\hline No & 261 & $33 \%$ \\
\hline \multicolumn{3}{|l|}{ Income status } \\
\hline$<3000$ Turkish Liras & 64 & $8 \%$ \\
\hline$\geq 3000$ Turkish Liras & 717 & $92 \%$ \\
\hline \multicolumn{3}{|l|}{ Profession } \\
\hline Physician & 28 & $4 \%$ \\
\hline Nurse & 134 & $17 \%$ \\
\hline Emergency medical technician & 434 & $56 \%$ \\
\hline Paramedic & 185 & $24 \%$ \\
\hline \multicolumn{3}{|l|}{ Years of seniority } \\
\hline $0-9$ years & 391 & $50 \%$ \\
\hline $10-19$ years & 328 & $42 \%$ \\
\hline $20+$ years & 62 & $8 \%$ \\
\hline \multicolumn{3}{|l|}{ Years of seniority in department } \\
\hline $0-9$ years & 539 & $69 \%$ \\
\hline $10-19$ years & 219 & $28 \%$ \\
\hline $20+$ years & 23 & $3 \%$ \\
\hline
\end{tabular}

\section{TABLE 2. Total scores of the participants}

\begin{tabular}{|c|c|c|c|c|}
\hline \multirow[b]{2}{*}{ Participants } & & \multicolumn{3}{|c|}{ Scale scores } \\
\hline & & $\begin{array}{c}\text { Internal } \\
\text { satisfaction }\end{array}$ & $\begin{array}{l}\text { External } \\
\text { satisfaction }\end{array}$ & $\begin{array}{c}\text { General } \\
\text { satisfaction }\end{array}$ \\
\hline Total & Median (min-max) & $3.5(\mid-5)$ & $3(1-5)$ & $3.2(1-5)$ \\
\hline$n=781(100 \%)$ & Mean \pm SD & $3.4 \pm 0.6$ & $2.9 \pm 0.7$ & $3.2 \pm 0.6$ \\
\hline
\end{tabular}

In Table 4, the opinions of 14 participants on factors affecting job satisfaction were grouped under four categories. The answers of the participants according to the in-depth analysis were presented below. These data were obtained from the written opinions of the participants (Table 4).

\begin{tabular}{|c|c|c|c|}
\hline & $\begin{array}{l}\text { Internal } \\
\text { satisfaction }\end{array}$ & $\begin{array}{l}\text { External } \\
\text { satisfaction }\end{array}$ & $\begin{array}{c}\text { General } \\
\text { satisfaction }\end{array}$ \\
\hline Variables & $\begin{array}{l}\text { Median } \\
(\min , \max )\end{array}$ & $\begin{array}{l}\text { Median } \\
(\min , \max )\end{array}$ & $\begin{array}{l}\text { Median } \\
(\min , \max )\end{array}$ \\
\hline \multicolumn{4}{|l|}{ Age } \\
\hline I8-25 years & $3.67(1,5)$ & $3(1,5)$ & $3.3(I, 5)$ \\
\hline $26-35$ years & $3.58(I, 5)$ & $3(1,5)$ & $3.25(I, 5)$ \\
\hline $36-45$ years & $3.5(I, 4.92)$ & $3.13(1,4.63)$ & $3.3(1,4.8)$ \\
\hline $46-55$ years & $3.75(1.33,4.75)$ & $3.5(1.5,4.75)$ & $3.55(1.4,4.75)$ \\
\hline$\chi^{2}, p$ & $2.459,0.483$ & $4.225,0.238$ & $3.997,0.262$ \\
\hline \multicolumn{4}{|l|}{ Gender } \\
\hline Female & $3.58(I, 5)$ & $3(1,5)$ & $3.25(I, 5)$ \\
\hline Male & $3.67(1,5)$ & $3(1,5)$ & $3.35(1,5)$ \\
\hline Z, p & $1.524,0.127$ & $2.189,0.029$ & $2.073,0.038$ \\
\hline \multicolumn{4}{|l|}{ Educational status } \\
\hline High school graduate & $3.58(1,4.75)$ & $3(I, 4.75)$ & $3.35(1,4.65)$ \\
\hline Bachelor's degree & $3.58(I, 5)$ & $3(1,5)$ & $3.25(I, 5)$ \\
\hline$Z, p$ & $0.655,0.512$ & $0.744,0.457$ & $0.935,0.350$ \\
\hline \multicolumn{4}{|l|}{ Marital status } \\
\hline Married & $3.58(I, 5)$ & $3(1,5)$ & $3.3(I, 5)$ \\
\hline Single & $3.5(I, 4.92)$ & $3(1,4.5)$ & $3.2(1,4.75)$ \\
\hline Others & $3.5(1,4.58)$ & $3.13(1,4.25)$ & $3.45(1,4.45)$ \\
\hline$\chi^{2}, p$ & $3.231,0.199$ & $3.699,0.157$ & $4.429,0.109$ \\
\hline \multicolumn{4}{|l|}{ Having children } \\
\hline Yes & $3.58(I, 5)$ & $3(1,5)$ & $3.3(I, 5)$ \\
\hline No & $3.5(I, 5)$ & $3(1,5)$ & $3.26(I, 4.8)$ \\
\hline$Z, p$ & $1.679,0.093$ & $1.347,0.178$ & $1.532,0.125$ \\
\hline \multicolumn{4}{|l|}{ Income status } \\
\hline <3000 Turkish Liras & $3.75(\mathrm{l}, 4.58)$ & $3.06(1,4.38)$ & $3.4(1,4.5)$ \\
\hline$\geq 3000$ Turkish Liras & $3.58(1,5)$ & $3(1,5)$ & $3.3(1,5)$ \\
\hline Z,p & $1.650,0.099$ & $0.097,0.923$ & $0.935,0.350$ \\
\hline \multicolumn{4}{|l|}{ Profession } \\
\hline Physician & $3.65(2.67,4.33)$ & $3.06(1.5,4.25)$ & $3.35(2.4,4)$ \\
\hline Nurse & $3.67(\mathrm{l}, 4.92)$ & $3(\mathrm{I}, 4.63)$ & $3.38(\mathrm{l}, 4.8)$ \\
\hline $\begin{array}{l}\text { Emergency medical } \\
\text { technician }\end{array}$ & $3.58(1,5)$ & $3(1,5)$ & $3.28(1,5)$ \\
\hline Paramedic & $3.58(1.08,4.83)$ & $3(1,5)$ & $3.25(1.05,4.8)$ \\
\hline$\chi^{2}, p$ & $2.619,0.454$ & I. $114,0.774$ & $2.172,0.537$ \\
\hline \multicolumn{4}{|l|}{ Years of seniority } \\
\hline $0-9$ years & $3.61(1,5)$ & $3(1,5)$ & $3.3(1,5)$ \\
\hline $10-19$ years & $3.5(1,5)$ & $3(1,5)$ & $3.25(1,5)$ \\
\hline $20+$ years & $3.58(1.33,4.92)$ & $3.25(1.5,4.75)$ & $3.45(1.4,4.8)$ \\
\hline$\chi^{2}, p$ & $1.648,0.439$ & $4.987,0.083$ & $4.321,0.115$ \\
\hline \multicolumn{4}{|c|}{ Years of seniority in department } \\
\hline $0-9$ years & $3.58(1,5)$ & $3(1,5)$ & $3.3(I, 5)$ \\
\hline $10-19$ years & $3.58(1.92,5)$ & $3(1,5)$ & $3.25(1.85,5)$ \\
\hline $20+$ years & $3.5(1.33,4.33)$ & $3(1.5,4.38)$ & $3.3(1.4,4.15)$ \\
\hline$\chi^{2}, p$ & $0.004,0.998$ & $0.860,0.651$ & $0.521,0.771$ \\
\hline
\end{tabular}


TABLE 4. Opinions of the participants on the factors affecting job satisfaction

\section{Positive factors}

Physical causes

External causes

Being appreciated by directors. When patients or their relatives are grateful to the employees.

Internal causes Saving lives of patients. Successful interventions. Employees are proud of their work. Employees' loving his/her profession. Feeling special because of his/her profession.

Social causes

\section{Negative factors}

Poor physical conditions of ambulance stations.

Uniforms are non-ergonomic and not in the correct color.

Design of ambulances.

Difficulties in transportation to the work.

Inability to access directors.

Not taking into consideration the

recommendations of employees by directors.

Employees are not given the right to make

their own decisions.

Not being appreciated.

Absence of career opportunities.

Scientific studies are not supported.

Intensive work.

Lack of personnel number.

Low wages.

Unpaid premiums and unfair distribution

of premiums.

Serving non-emergent cases.

Lack of safety measures.

Exposure to physical and verbal violence.

Prejudiced behaviors of hospital emergency

department professionals.

Failure of intervention.

\section{Factors increasing the satisfaction}

Improvement of physical conditions in stations and ambulances.

Easy transportation to work.

Ergonomic uniforms.

Being appreciated by directors and patients.

Career opportunities.

A fair wage system based on the level of education, performance, and career. Serving only emergent cases.

Professional development and career opportunities.

Providing security measures.

Providing measures related to violence.

Reduction in prejudices.

\author{
Good image of the profession in \\ society. \\ Teamwork \\ Strong communication.
}

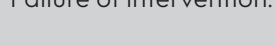


satisfaction. In our study, external satisfaction and general satisfaction rates of female employees are lower than those of male employees. This is thought to be due to the fact that females are more sensitive, deal with housework and childcare, and working in pre-hospital EMS requires intense physical force.

When the opinions of the participants are examined, it is seen that they mostly have positive considerations on internal causes. In accordance with the structure and aim of the pre-hospital EMS, the successful interventions of the employees to save lives can be considered as one of the most important factors that enable them to be satisfied by their jobs. The factors negatively affecting employees' job satisfaction are generally external factors. Wage distribution, education level, career opportunities, security measures, prevention of violence, managerial problems, and non-emergent cases are important issues in this field.

The participants also mentioned that the ergonomics of their uniforms and of emergency aid bags were factors affecting their job satisfaction. There are no studies in the literature on this subject. However, considering that EMS is a work that requires constant and rapid movement, the ergonomics of uniforms and bags can significantly affect the operation of the work. New studies should be conducted on this issue.

In the study conducted by Khatiban et al. (18), the participants generally perceived participation in managerial decisions related to their work as inadequate, and they considered this as an obstacle to job satisfaction. They also stated that the quality of existing equipment and materials, planning of work shifts, lack of coordination between personnel, and verbal and physical violence are factors that negatively affect job satisfaction. In the study conducted by Andel et al. (19), it was found that low job satisfaction was reflected on the performance of the employees, and that this reflection caused verbal violence when noticed by the patients and their relatives. In other words, violence decreases job satisfaction, and decreasing job satisfaction causes violence again.

In pre-hospital EMS, the working environment is often seen as unsafe environments by employees. In the study by Ujevic et al. (2), it was found that employees working at the ambulance had lower job satisfaction than those working in the call center or in the office of the EMS. The findings of the present study are similar to those in the literature.

The present study is limited to the city where the study was conducted. EMS employees in other cities may have different results. Since the literature on the EMS field is insufficient, no clear comparison could be made.

The external satisfaction level of EMS professionals is low. Problems related to access to management, participation in management, career opportunities, wages, security, being appreciated, and prevention of violence negatively affect job satisfaction. It may not be possible to eliminate these issues completely, but improvements are recommended. Different factors, such as appreciation, rewarding, personal accomplishment, merit, and social opportunities, that positively affect job satisfaction should be supported and increased.

Ethics Committee Approval: Ethics committee approval was received for this study from Ankara Yıldırım Beyazıt University (Approval Date: 18/09/2018, Approval Number: 41).
Informed Consent: Written informed consent was obtained from the individuals who accepted to participate in the study.

Peer-review: Externally peer-reviewed.

Acknowledgements: We would like to thank Erdener BATAR and Günseli UZUNHASANOĞLU for their contribution to the statistical analysis, and translation of the study.

Conflict of Interest: The author has no conflicts of interest to declare.

Financial Disclosure: The author declared that this study has received no financial support.

\section{REFERENCES}

I. Iliopoulos E, Morrissey N, Baryeh K, Polyzois I. Correlation between workplace learning and job satisfaction of NHS healthcare professionals. Br J Healthcare Management 2018; 24(5): 226-33. [CrossRef]

2. Ujevic RM, Prizmic J, Barisin AB, Maras $M$, Luetic $L$. Is there a difference in job satisfaction at emergency medicine service (EMS) team and EMS dispatchers? Resuscitation 2018; 130(I): 140. [CrossRef]

3. Ganapathy S, Ashokkumar M. A Study On Human Resource Management Practices (Hrm) And. IJMRR 20I7; 7(5): 584-95. [CrossRef]

4. Riketta M. The causal relation between job attitudes and performance: A meta-analysis of panel studies. J Appl Psychol 2008; 93(2): 472-8I. [CrossRef]

5. Atan M, Tekingündüz S. Ambulans çalıșanlarının (II2) tükenmișlik, algılanan iș stresi ve iș tatminlerinin kișisel özelliklere göre incelenmesi. NWSA-Social Sciences 20I4; 9(3): 54-69. [CrossRef]

6. Judge TA, Kammeyer-Mueller JD. Job attitudes. Annu Rev Psychol 2012; 63: 34I-67. [CrossRef]

7. Durmuș $\mathrm{S}$, Günay $\mathrm{O}$. Hemșirelerde iș doyumu ve anksiyete düzeyini etkileyen faktörler. Erciyes Tıp Derg 2007; 29(2): 139-46.

8. Srivastava BP, Singh M. Job satisfaction among healthcare professional in public and private healthcare setup in India. PIJR 2017; 6(I): 6-8.

9. Fahrenkopf AM, Sectish TC, Barger LK, Sharek PJ, Lewin D, Chiang VW, et al. Rates of medication errors among depressed and burnt out residents: prospective cohort study. BMJ 2008; 336: 488-91. [CrossRef]

I0. Schaaijk V, Boschman JS, Frings-Dresen MHW, Sluiter JK. Appraisal of work ability in relation to job-specific health requirements in ambulance workers. Int Arch Occup Environ Health 2017; 90(I): 123-31. [CrossRef]

II. Crowe RP, Bower JK, Cash RE, Panchal AR, Rodriguez SA, Olivo-Marston SE. Association of Burnout with Workforce-Reducing Factors among EMS Professionals. Prehosp Emerg Care 2017; 22(2): 229-36. [CrossRef]

12. Coxon A, Cropley M, Schofield P, Start K, Horsfield C, Quinn T. 'You're never making just one decision': exploring the lived experiences of ambulance Emergency Operations Centre personnel. Emerg Med J 2016; 33: 645-5I. [CrossRef]

13. Alexander DA, Klein S. Ambulance personnel and critical incidents: Impact of accident and emergency work on mental health and emotional well-being. Br J Psychiatry 200I; I78(I): 76-8I. [CrossRef]

14. Tarcan M, Hikmet N, Schooley B, Top M, Yorgancıoglu Tarcan G. An analysis of the relationship between burnout, socio-demographic and workplace factors and job satisfaction among emergency department health professionals. Appl Nurs Res 2017; 34: 40-7. [CrossRef]

15. Weiss DJ, Dawis RV, England GW. Manual for the Minnesota Satisfaction Questionnaire. Minnesota Studies in Vocational Rehabilitation 1967; 22: 120. [CrossRef]

16. Baycan A. Analysis of Several Aspects of Job Satisfaction Between Different Occupational Groups. Yayınlanmamıș Yüksek Lisans Tezi, Boğaziçi Üniversitesi, İstanbul, 1985.

17. Duran A, Ocak T, Yorgun S, Koç D. II2 Ambulans Servisinde Çalıșan Memnuniyeti. Abant Med J 20I2; I(3): 144-8. [CrossRef] 
18. Khatiban HS, Bikmoradi R, Karampourian A. Job satisfaction level and its main determinants among Iranian emergency medical service personnel: A population-based survey. AJP 2014; II(4): I-8. [CrossRef]
19. Andel SA, Pindek S, Spector PE. When antecedent becomes consequent: An examination of the temporal order of job dissatisfaction and verbal aggression exposure in a longitudinal study. J Work Stress 2018; II3. [CrossRef] 